\section{TUGAS PEMERINTAH DALAM MENGAWASI AKTIVITAS PERTAMBANGAN EMAS YANG TIDAK MENJALANKAN KEWAJIBAN IZIN USAHA PERTAMBANGAN (IUP) BERDASARKAN UU NO 4 TAHUN $2009^{1}$ \\ Oleh : Alva Ryan Kambey ${ }^{2}$}

\begin{abstract}
ABSTRAK
Tujuan dilakukannya penelitian ini adalah untuk mengetahui bagaimana Penyesuaian Kewenangan Negara atas Pengelolaan Pertambangan Mineral dan Batubara Setelah Berlaku Undang-Undang No 23 Tahun 2014 Tentang Pemerintahan Daerah dan bagaimana Pengawasan Pemerintah atas Pelaksanaan Kegiatan Usaha Pertambangan Yang Telah Memiliki IUP serta bagaimana Tugas Pemerintah Terhadap Aktifitas Pertambangan Emas Yang Tidak Menjalankan Kewajiban Izin Usaha Pertambangan (IUP). Dengan menggunakan metode penelitian yuridis normatif, disimpulkan: 1 . Dengan berlakunya undang-undang pemerintahan daerah, penyelenggaraan Urusan Pemerintahan bidang kehutanan, kelautan, serta energi dan sumber daya mineral dibagi antara pemerintah pusat dan daerah provinsi. pertambangan mineral dan batubara sebagai bagian dari energi dan sumber daya mineral menjadi urusan Pemerintah Pusat dan Pemerintah Daerah Provinsi, sedangkan untuk daerah
\end{abstract} kabupaten/kota tidak memegang kewenangan samasekali termasuk dalam pemberian Izin Usaha Pertambangan (IUP) tetapi kedudukan undang-undang pemerintahan daerah tidak mencabut kekuatan hukum dari undangundang No. 4 tahun 2009 tentang pertambangan mineral dan batubara, namun harus di lakukan penyesuaian mengenai kewenangan pengelolaan dan pengawasan Pertambangan mineral dan batubara. 2 . Pengawasan pemerintah terhadap pelaksanaan kegiatan usaha pertambangan terbagi dalam dua macam pengawasan, yaitu: Pengawasan yang di lakukan oleh menteri terhadap gubernur sebagai penanggungjawab penyelenggara pengelolaan usaha pertambangan di era otonomi daerah sesuai

\footnotetext{
${ }^{1}$ Artikel Skripsi. Dosen Pembimbing: Dr. Flora Pricilla Kalalo, SH, MH; Henry R. Ch, Memah, SH, MH

2 Mahasiswa pada Fakultas Hukum Unsrat, NIM. 16071101357
}

kewenangannya. 3. Pengawasan yang dilakukan oleh pemerintah dan pemerintah daerah (menteri, gubernur) ditujukan terhadap pelaku usaha pertambangan. 3. Penerapan Hukum yang dapat dilakukan oleh pemerintah dalam mengatasi Aktifitas pertambangan emas yang tidak menjalankan kewajiban usaha pertambangan berdasarkan Undang-Undang No. 4 Tahun 2009 Tentang Pertambangan Mineral dan Batubara adalah menjatuhkan sanksi berupa sanksi administratif dalam bentuk : Peringatan tertulis; Penghentian sementara sebagian atau seluruh kegiatan eksplorasi atau operasi produksi; dan/atau Pencabutan IUP. Pejabat yang berhak menjatuhkan sanksi adalah pemerintah (menteri) dan pemerintah daerah provinsi. Dalam hal pemerintah daerah tidak melaksanakan ketentuan sebagaimana yang dimaksud dalam pasal 151 dan hasil evaluasi yang dilakukan oleh menteri sebagaimana dimaksud dalam pasal 6 ayat (1) huruf j, Menteri dapat menghentikan sementara dan/atau mencabut IUP sesuai dengan ketentuan peraturan perundang-undangan.

Kata kunci: Tugas Pemerintah, Mengawasi, Aktivitas Pertambangan Emas, Tidak Menjalankan Kewajiban Izin Usaha Pertambangan.

\section{PEMBAHASAN}

A. Penyesuaian Kewenangan Negara atas Pengelolaan Pertambangan Mineral dan Batubara Setelah Berlaku Undang-Undang No 23 Tahun 2014 Tentang Pemerintahan Daerah

Menurut Pasal 8 Undang-Undang No 4 Tahun 2009 Tentang pertambangan Mineral dan Batubara/ Sebelum berlakunya UndangUndang No 23 Tahun tentang Pemerintahan Daerah.

Kewenangan pemerintah kabupaten/kota dalam pengelolaan pertambangan mineral dan batubara, antara lain, adalah:

a. Pembuatan peraturan perundangundangan daerah;

b. Pemberian IUP dan IPR, pembinaan, penyelesaian konflik masyarakat, dan pengawasan usaha pertambangan di wilayah kabupaten/kota dan/atau wilayah laut sampai dengan 4 (empat) mil; 
c. Pemberian IUP dan IPR, pembinaan, penyelesaian konflik masyarakat dan pengawasan usaha pertambangan operasi produksi yang kegiatannya berada di wilayah kabupaten/kota dan/atau wilayah laut sampai dengan 4 (empat) mil;

d. Penginventarisasian, penyelidikan dan penelitian, serta eksplorasi dalam rangka memperoleh data dan informasi mineral dan batubara;

e. Pengelolaan informasi geologi, informasi potensi mineral dan batubara, serta informasi pertambangan pada wilayah kabupaten/kota;

f. Penyusunan neraca sumber daya mineral dan batubara pada wilayah kabupaten/kota;

g. Pengembangan dan pemberdayaan masyarakat setempat dalam usaha pertambangan dengan memperhatikan kelestarian lingkungan;

h. Pengembangan dan peningkatan nilai tambah dan manfaat kegiatan usaha pertambangan secara optimal;

i. Penyampaian informasi hasil inventarisasi, penyelidikan umum, dan penelitian, serta eksplorasi dan eksploitasi kepada Menteri dan gubernur;

j. Penyampaian informasi hasil produksi, penjualan dalam negeri, serta ekspor kepada Menteri dan gubernur;

k. Pembinaan dan pengawasan terhadap reklamasi lahan pascatambang; dan

I. Peningkatan kemampuan aparatur pemerintah kabupaten/kota dalam penyelenggaraan pengelolaan usaha pertambangan.

Dalam Pasal 14 ayat (1) Undang-Undang Nomor 23 Tahun 2014 tentang pemerintahan daerah disebutkan bahwa : Penyelenggaraan Urusan Pemerintahan bidang kehutanan, kelautan, serta energi dan sumber daya mineral dibagi antara pemerintah pusat dan daerah provinsi. ${ }^{3}$ Energi dan Sumber Daya Mineral menjadi kewenangan Pemerintah Pusat dan Pemerintah Daerah Provinsi, yang berarti bahwa, pertambangan mineral dan batubara sebagai bagian dari energi dan

\footnotetext{
${ }^{3}$ Undang-Undang No 23 Tahun 2014 Tentang Pemerintah Daerah Pasal. 14 ayat 1.
}

sumber daya mineral menjadi urusan Pemerintah Pusat dan Pemerintah Daerah Provinsi.

Setelah berlakunya Undang-Undang tentang Pemerintahan Daerah, kewenangan pemberian IUP yang bersifat Penanaman Modal Asing (PMA) dan Penanaman Modal Dalam Negeri (PMDN) dipisahkan, IUP dalam rangka PMA diberikan oleh Pemerintah Pusat sedangkan IUP dalam rangka PMDN diberikan oleh Pemerintah Pusat dan Provinsi. Wilayah untuk IUP dalam rangka PMA yang dapat diberikan oleh pemerintah pusat adalah Wilayah Izin Usaha Pertambangan (WIUP) lintas provinsi maupun dalam wilayah provinsi dan wilayah laut lebih dari 12 mil. Wilayah untuk IUP dalam rangka PMDN yang dapat diberikan oleh pemerintah pusat adalah Wilayah Izin Usaha Pertambangan (WIUP) wilayah laut lebih dari 12 mil. Sedangkan Wilayah untuk IUP dalam rangka PMDN yang dapat diberikan oleh pemerintah provinsi adalah WIUP dalam satu wilayah provinsi dan wilayah laut sampai dengan 12 mil.

\section{B. Pengawasan Pemerintah Atas Pelaksanaan Kegiatan Usaha Pertambangan Yang Telah Memiliki IUP}

Terkait pengawasan pemerintah terhadap pelaksanaan kegiatan usaha pertambangan, pada dasarnya diatur dalam Pasal 140 ayat (1), ayat (2) dan ayat (3) Undang-Undang Nomor 4 Tahun 2009 tentang Pertambangan Mineral dan Batubara, yang menyatakan bahwa :

(1) Menteri melakukan pengawasan terhadap penyelenggaraan pengelolaan usaha pertambangan yang dilaksanakan oleh pemerintah provinsi dan pemerintah kabupaten/kota sesuai dengan kewenangannya.

(2) Menteri dapat melimpahkan kepada gubernur untuk melakukan pengawasan terhadap penyelenggaraan kewenanganpengelolaan di bidang usaha pertambangan sebagaimana dimaksud pada ayat (1) yang dilaksanakan oleh pemerintah kabupaten/kota.

(3) Menteri, gubernur, dan bupati/walikota sesuai dengan kewenangannya melakukan pengawasan atas pelaksanaan kegiatan usaha 
pertambangan yang dilakukan oleh pemegang IUP, IPR, atau IUPK. ${ }^{4}$

Bentuk pengawasan menurut ketentuan pasal tersebut, apabila dilihat dari sisi objeknya dapat dibagi ke dalam 2 (dua) macam pengawasan, yaitu :

1. Pengawasan internal atau pengawasan vertikal, adalah pengawasan yang dilakukan oleh menteri terhadap gubernur, bupati/walikota sebagai penanggungjawab penyelenggara pengelolaan usaha pertambangan di daerah sesuai kewenangannya, sebagaimana diatur dalam ketentuan Pasal 140 ayat (1) ; dan (2)

2. Pengawasan eksternal atau pengawasan fungsional, yang dilakukan oleh menteri, gubernur, bupati/walikota ditujukan terhadap pelaku usaha pertambangan, sebagaimana diatur dalam ketentuan Pasal 140 ayat (3). Ruang lingkup pengawasan fungsional diatur dalam ketentuan Pasal 141 Undang-undang No 4 Tahun 2009 Tentang Pertambangan Mineral dan Batubara, yang meliputi aspek-aspek sebagai berikut :

a. Teknis pertambangan

Pengawasan teknis pertambangan dilakukan oleh Inspektur Tambang yang meliputi:

a) IUP atau IUPK Eksplorasi dilakukan paling sedikit terhadap:

1. Pelaksanaan teknik eksplorasi; dan

2. Tata cara penghitungan sumber daya dan cadangan.

b) IUP atau IUPK Operasi Produksi paling sedikit terhadap:

1. Perencanaan dan pelaksanaan konstruksi termasuk pengujian alat pertambangan (commisioning);

2. Perencanaan dan pelaksanaan penambangan;

3. Perencanaan dan pelaksanaan pengolahan dan pemurnian; dan

4. Perencanaan dan pelaksanaan pengangkutan dan penjualan.

b. Pemasaran

Pengawasan dilakukan oleh pejabat pengawas yang ditunjuk oleh

4 Undang-undang No 4 Tahun 2009 Tentang Pertambangan Mineral dan Batubara, Pasal 140 menteri, gubernur, atau bupati/walikota terhadap :

1) Realisasi produksi dan realisasi penjualan termasuk kualitas dan kuantitas serta harga mineral dan batubara;

2) Kewajiban pemenuhan kebutuhan mineral atau batubara untuk kepentingan dalam negeri;

3) Rencana dan realisasi kontrak penjualan mineral atau batubara;

4) biaya penjualan yang dikeluarkan;

5) Perencanaan dan realisasi penerimaan negara bukan pajak; dan

6) Biaya pengolahan dan pemurnian mineral dan/atau batubara.

c. Keuangan

Pengawasan dilakukan oleh pejabat pengawas yang ditunjuk oleh menteri, gubernur, atau bupati/walikota sesuai dengan kewenangannya yang meliputi:

1) Perencanaan

anggaran;

2) Realisasi anggaran;

3) Realisasi investasi; dan

4) Pemenuhan kewajiban pembayaran.

Adapun pemenuhan kewajiban pembayaran paling sedikit meliputi:

1) luran tetap untuk WIUP mineral logam, WIUP batubara WPR, atau WIUPK;

2) luran produksi mineral logam, batubara, dan mineral bukan logam sesuai dengan ketentuan peraturan perundang-undangan; dan

3) Pembayaran sebesar $10 \%$ (sepuluh persen) dari keuntungan bersih bagi pemegang IUPK Operasi Produksi mineral logam atau batubara.

d. Pengolahan data mineral dan batubara Pengawasan dilakukan oleh pejabat pengawas yang 
ditunjuk oleh menteri, gubernur, atau bupati/walikota terhadap kegiatan perolehan, pengadministrasian, pengolahan, penataan, penyimpanan, pemeliharaan, dan pemusnahan data dan/atau informasi.

e. Konservasi sumber daya mineral dan batubara.

Pengawasan dilakukan oleh Inspektur tambang yang meliputi :

1) Recovery penambangan dan pengolahan;

2) Pengelolaan dan/atau pemanfaatan cadangan marginal;

3) Pengelolaan dan/atau pemanfaatan batubara kualitas rendah dan mineral kadar rendah;

4) Pengelolaan dan/atau pemanfaatan mineral ikutan;

5) Pendataan sumber daya serta cadangan mineral dan batubara yang tidak tertambang; dan

6) Pendataan dan pengelolaan sisa hasil pengolahan dan pemurnian.

f. Keselamatan dan kesehatan kerja pertambangan Pengawasan dilakukan oleh Inspektur Tambang berkoordinasi dengan pengawas ketenagakerjaan yang meliputi :

1) Keselamatan kerja, yang antara lain terdiri atas : manajemen risiko; program keselamatan kerja antara lain, pencegahan kecelakan, peledakan, kebakaran, dan kejadian lain yang berbahaya; pelatihan dan pendidikan keselamatan kerja; administrasi keselamatan kerja; manajemen keadaan darurat; inspeksi keselamatan kerja; serta pencegahan dan penyelidikan kecelakaan.

2) Kesehatan kerja, yang antara lain terdiri atas program kesehatan pekerja/buruh yang meliputi, pemeriksaan kesehatan tenaga kerja, pelayanan kesehatan kerja, pencegahan penyakit akibat kerja, pertolongan pertama pada kecelakaan, serta pelatihan dan pendidikan kesehatan kerja; higienis dan sanitasi; ergonomis; pengelolaan makanan, minuman, dan gizi pekerja/buruh; dan/atau dianogsis dan pemeriksaan penyakit akibat kerja.

3) Lingkungan kerja, yang terdiri atas: pengendalian debu; pengendalian kebisingan; pengendalian getaran; pencahayaan; kualitas udara kerja; pengendalian radiasi; pengendalian faktor kimia; pengendalian faktor biologi; dan kebersihan lingkungan kerja.

4) Sistem manajemen keselamatan dan kesehatan kerja.

g. Keselamatan operasi pertambangan Pengawasan dilakukan oleh Inspektur Tambang dan dapat berkoordinasi dengan pengawas ketenagakerjaan yang meliputi :
1) Sistem dan pelaksanaan pemeliharaan/perawatan sarana, prasarana, instalasi, dan peralatan pertambangan;
2) Pengamanan instalasi;
3) Kelayakan sarana, prasarana instalasi, dan peralatan pertambangan;
4) Kompetensi tenaga teknik; dan
5) Evaluasi laporan hasil kajian teknis pertambangan.

h. Pengelolaan lingkungan hidup, reklamasi dan pascatambang Pengawasan dilakukan oleh Inspektur Tambang dan berkoordinasi dengan pengawas di bidang lingkungan hidup dan di bidang reklamasi.

i. Pemanfaatan barang, jasa, teknologi dan kemampuan rekayasa dan rancang bangun dalam negeri.

Pengawasan dilakukan oleh Inspektur Tambang terhadap pelaksanaan pemanfaatan barang, jasa, teknologi, serta kemampuan rekayasa dan rancang bangun. Penggunaan barang, jasa, teknologi, serta kemampuan rekayasa dan rancang bangun dilaksanakan sesuai dengan klasifikasi dan 
kualifikasi pelaksana usaha jasa pertambangan mineral dan batubara.

j. Pengembangan tenaga kerja teknis pertambangan

Pengawasan dilakukan oleh pejabat yang ditunjuk oleh menteri, gubernur, atau bupati/walikota sesuai dengan kewenangannya yang terdiri dari :

1) Pelaksanaan program pengembangan;

2) Pelaksanaan uji kompetensi; dan

3) Rencana biaya pengembangan.

k. Pengembangan dan pemberdayaan masyarakat setempat.

I. Kegiatan-kegiatan lain di bidang kegiatan usaha pertambangan yang menyangkut kepentingan umum Pengawasan dilakukan oleh pejabat yang ditunjuk oleh menteri, gubernur, atau bupati/walikota, meliputi:

1) Fasilitas umum yang dibangun oleh pemegang IUP atau pemegang IUPK untuk masyarakat sekitar tambang; dan

2) Pembiayaan untuk pembangunan atau penyediaan fasilitas umum.

m. Pengelolaan IUP, IPR dan IUPK Pengawasan dilakukan oleh pejabat yang ditunjuk oleh menteri, gubernur, atau bupati/walikota terhadap pelaksanaan kegiatan sesuai dengan IUP, IPR, atau IUPK yang terdiri dari:

1) Luas wilayah;

2) Lokasi penamb angan;

3) Lokasi pengolahan dan pemurnian;

4) Jangka waktu tahap kegiatan;

5) Penyelesaian masalah pertanahan;

6) Penyelesaian perselisihan; dan Penguasaan, pengembangan, dan penerapan teknologi pertambanganmineral atau batubara.

n. Jumlah, jenis dan mutu hasil usaha pertambangan Pengawasan dilakukan oleh pejabat yang ditunjuk oleh menteri, gubernur, atau bupati/walikota yang meliputi :

1) Jenis komoditas tambang;

2) Kuantitas dan kualitas produksi untuk setiap lokasi penambangan;

3) Kuantitas dan kualitas pencucian dan/atau pengolahan dan pemurnian; dan

4) Tempat penimbunan sementara (run of mine), tempat penimbunan (stock pile), dan titik serah penjualan (at sale point). ${ }^{5}$

\section{Tugas Pemerintah Terhadap Aktifitas Pertambangan Emas Yang Tidak Menjalankan Kewajiban Izin Usaha Pertambangan (IUP)}

1. Pengertian Sanksi Admnistratif

Istilah sanksi administratif berasal dari terjemahan bahasa inggris, yaitu administrative sancties. Sanksi administrative berasal dari dua suku kata , yaitu sanksi dan administratif. ${ }^{6}$

Sanksi administrative adalah :

" sanksi yang mungkin dijatuhkan atau di paksakan secara langsung oleh instansi pemerintah, yang berwenang tanpa menunggu perintah pengadilan. Di Indonesia di asumsikan bahwa penjatuhan sanksi administratif, mensyaratkan kaitan yang telah ada sebelumnya, seperti izin usaha yang telah dikeluarkan oleh instansi pemerintah untuk menjalankan bisnis. Sanksi administratif dapat didasarkan kepada pelanggaran sesuatu atau beberapa kondisi yang di syaratkan oleh izin tersebut". Kontruksi sanksi administratif dalam definisi ini, yaitu pada penjatuhan atau pemaksaan sanksi. Sanksi dilakukan oleh instansi pemerintah terhadap orang atau badan hukum

\footnotetext{
${ }^{5}$ Govinda Panjuwa “Hak dan Kewajiban Pemegang Izin Usaha Pertambangan (IUP) dalam melaksanakan kegiatan usaha pertambangan", https://ejournal.unsrat.ac.id,. HIm.4.

${ }^{6}$ H. Salim HS., Hukum Pertambangan Mineral dan Batubara. (Jakarta: Sinar Grafika, 2014), Cet. 3, HIm. 266.
} 
yang menjalankan bisnis berdasarkan izin yang diberikan kepadanya. ${ }^{7}$

Data Pendukung :

"Di daerah antara Kabupaten Minahasa Utara dan Kota Bitung terdapat aktifitas perusahan Mineral dan Batubara yang bergerak di bidang Pertambangan emas yang telah memiliki Izin Usaha Pertambangan, namun aktifitas kegiatan dari perusahan tersebut meresahkan masyarakat lingkar tambang, yang di anggap Masyarakat tidak menaati Kewajiban Izin usaha Pertambangan yaitu :

1. Kegiatan perusahan tambang emas sudah sangat dekat dengan pemukiman warga.

2. Melakukan bom bawah tanah dua kali sehari, di dalam wilayah pemukiman warga yang mengakibatkan batu-batu pecahan terpancar dan mengenai rumah-rumah warga, dan retak di bagian dinding-dinding rumah warga.

3. Bom bawah tanah tersebut pernah mengakibatkan seorang warga masyarakat meninggal karena sakit jantung.

4. Bising alat kegiatan tambang emas yg beraktifitas $1 \times 24$ jam di dekat pemukiman warga, yang mengakibatkan warga masyarakat tidak bisa beristirahat dengan tenang

5. Lingkungan yang tercemar karena adanya zat-zat kimia dari kegiatan pertambangan emas tersebut.

6. lapangan pekerjaan yang tidak di utamakan bagi masyarakat Lokal.

7. Serta Pemberdayaan Masyarakat yang tidak merata.

Dan pada Akhirnya Masyarakat setempat merasa tidak tahan lagi, maka masyarakat melapor kepada pemerintah setempat, dan segera mengadakan pertemuan dengan Pihak Perusahan Tambang Emas tersebut, dan pihak perusahan menjanjikan lapangan pekerjaan, dan akan memperbaiki rumah-rumah warga yang rusak, serta akan mengurangi aktifitas Bom di daerah pemukiman Masyarakat, tapi janji dari perusahan tambang tidak di tepati secara tpat waktu, bahkan ada beberapa kali tidak di tepati, karena masyarakat tidak tau harus mengambil langkah apa untuk mengatasi keresahan warga tersebut, maka Masyarakat

${ }^{7}$ H. Salim HS., Hukum Pertambangan Mineral dan Batubara. (Jakarta: Sinar Grafika, 2014), Cet. 3, HIm. 267268. sepakat untuk membentuk kelompok, dan melakukan tindakan llegal yaitu melakukan Blokade jalan dan penghentian secara paksah aktifitas pertambangan emas yang beroperasi di dekat pemukiman warga.

Berdasarkan Data Pendukung di atas, maka Penulis Ingin mencari solusi masalah tersebut dengan Menulis Skripsi ini, dengan mempertimbangkan peraturan perundangundangan yang berlaku.

Pasal-pasal pelanggaran yang dilakukan oleh pemegang izin usaha pertambangan emas tersebut yaitu :

1. Pasal 95 undang-undang no 4 tahun 2009 tentang mineral dan batubara. Meliputi :

a. Pemegang IUP tidak menerapkan kaidah teknik pertambangan yang baik;

b. Pemegang IUP tidak melaksanakan pengembangan dan pemberdayaan masyarakat setempat; dan ; asal 98 undang-undang no 4 tahun 2009 tentang mineral dan batubara yaitu pemegang IUP tidak menjaga kelestarian fungsi dan daya dukung sumberdaya air yang bersangkutan sesuai dengan peraturan perundang-undangan; Pasal 107 undangundang no 4 tahun 2009 tentang mineral dan batubara adalah karena badan usaha IUP tidak mengikut sertakan pengusaha local yang ada di daerah dalam melakukan operasi produksi. Pasal 108 ayat (1) undang-undang no 4 tahun 2009 tentang mineral dan batubara adalah karena pemegang IUP tidak menyusun program pengembangan dan pemberdayaan masyarakat.

\section{Sanksi Administratif}

Pasal 151

Menteri, gubernur, atau bupati/walikota sesuai dengan kewenangannya berhak memberikan sanksi administratif kepada pemegang IUP, IPR atau IUPK atas pelanggaran ketentuan sebagaimana dimaksud dalam Pasal 40 ayat (3), Pasal 40 ayat (5), Pasal 41, Pasal 43, Pasal 70, Pasal 71 ayat (1), Pasal 74 ayat (4), Pasal 74 ayat (6), Pasal 81 ayat (1), Pasal 93 ayat (3), Pasal 95, Pasal 96, Pasal 97, Pasal 98, Pasal 99, Pasal 100, Pasal 102, Pasal 103, Pasal 105 ayat (3), Pasal 105 ayat (4), Pasal 107, Pasal 108 ayat (1), Pasal 110, Pasal 111 ayat (1), Pasal 112 ayat (1), Pasal 114 
ayat (2), Pasal 115 ayat (2), Pasal 125 ayat (3), Pasal 126 ayat (1), Pasal 128 ayat (1), Pasal 129 ayat (1), atau Pasal 130 ayat (2).

(2). Sanksi administratif sebagaimana dimaksud pada ayat (1) berupa:

a. Peringatan tertulis;

b. Penghentian sementara sebagian atau seluruh kegiatan eksplorasi atau operasi produksi; dan/atau;

c. Pencabutan IUP, IPR, atau IUPK. ${ }^{8}$

3. pejabat yang berwenang menjatuhkan sanksi administratif

Pejabat yang berwenang menjatuhkan sanksi administratif kepada pelaku pelanggaran berdasarkan undang-undang no 4 tahun 2009 tentang pertambangan mineral dan batubara dan Pemyesuaian Kewenangan Setelah berlakunya UU No 23 Tahun 2014 Tentang Pemerintahan Daerah, yaitu : Pemerintah Pusat dan Pemerintah Daerah/Provinsi.

Bupati/walikota tidak lagi mempunyai kewenangan dalam penyelenggaraan urusan pemerintahan di bidang pertambangan mineral dan batubara terhitung sejak tanggal 2 oktober 2014.

Menteri energi dan sumber daya mineral menjatuhkan sanksi administratif kepada pemegang IUP dan IUPK. Penjatuhan sanksi administratif oleh menteri energi dan sumber daya mineral hanya terhadap pemegang IUP yang wilayah izin usaha pertambangan (WIUP) nya berbeda pada lintas wilayah provinsi dan pejabat yang menerbitkan IUP tersebut adala menteri energi dan sumber daya mineral sendiri. Gubernur hanya berwenang menjatuhkan sanksi administrative terhadap pemegang IUP, di mana wilayah WIUP berada pada lintas wilayah kabupaten/kota dalam 1 (satu) provinsi. Bupati/walikota berwenang menjatuhkan sanksi administrative terhadap pemegang IPR dan IUP. Bupati/walikota hanya berwenang menjatuhkan sanksi administrative apabila WIUP nya berada di dalam satu wilayah kabupaten/kota. ${ }^{9}$

Dalam hal pemerintah daerah tidak melaksanakan ketentuan sebagaimana dimaksud dalam Pasal 151 dan hasil evaluasi yang dilakukan oleh Menteri sebagaimana

\footnotetext{
8 Undang-undang No 4 Tahun 2009 Tentang Pertambangan Mineral dan Batubara, Pasal 51.

${ }^{9}$ H. Salim HS., op.cit., hlm. 268-269
}

dimaksud dalam Pasal 6 ayat (1) huruf j, Menteri dapat menghentikan sementara dan/atau mencabut IUP atau IPR sesuai dengan ketentuan peraturan perundangundangan. ${ }^{10}$

Dalam hal pemerintah daerah berkeberatan terhadap penghentian sementara dan/atau pencabutan IUP dan IPR oleh Menteri sebagaimana dimaksud dalam Pasal 152, pemerintah daerah dapat mengajukan keberatan sesuai dengan ketentuan peraturan perundang-undangan. ${ }^{11}$

Segala akibat hukum yang timbul karena penghentian sementara dan/atau pencabutan IUP, IPR atau IUPK sebagaimana dimaksud dalam Pasal 151 ayat (2) huruf b dan huruf $c$ diselesaikan sesuai dengan ketentuan peraturan perundang-undangan. ${ }^{12}$

Pemerintah daerah yang tidak memenuhi ketentuan sebagaimana dimaksud dalam Pasal 5 ayat (4) dikenai sanksi administratif berupa penarikan sementara kewenangan atas hak pengelolaan usaha pertambangan mineral dan batubara. ${ }^{13}$

\section{PENUTUP}

\section{A. Kesimpulan}

1. Dengan berlakunya undang-undang pemerintahan daerah, penyelenggaraan Urusan Pemerintahan bidang kehutanan, kelautan, serta energi dan sumber daya mineral dibagi antara pemerintah pusat dan daerah provinsi. pertambangan mineral dan batubara sebagai bagian dari energi dan sumber daya mineral menjadi urusan Pemerintah Pusat dan Pemerintah Daerah Provinsi, sedangkan untuk daerah kabupaten/kota tidak memegang kewenangan samasekali termasuk dalam pemberian Izin Usaha Pertambangan (IUP) tetapi kedudukan undang-undang pemerintahan daerah tidak mencabut kekuatan hukum dari undang-undang no 4 tahun 2009 tentang pertambangan

\footnotetext{
10 Undang-Undang No 4 Tahun 2009 Tentang Pertambangan Mineral Batubara, Pasal.152.

11 Undang-Undang No 4 Tahun 2009 Tentang Pertambangan Mineral Batubara, Pasal.153.

12 Undang-Undang No 4 Tahun 2009 Tentang Pertambangan Mineral Batubara, Pasal.155.

13 Undang-Undang No 4 Tahun 2009 Tentang Pertambangan Mineral Batubara, Pasal.157.
} 
mineral dan batubara, namun harus di lakukan penyesuaian mengenai kewenangan pengelolaan dan pengawasan Pertambangan mineral dan batubara.

2. Pengawasan pemerintah terhadap pelaksanaan kegiatan usaha pertambangan terbagi dalam dua macam pengawasan, yaitu:

(a) Pengawasan yang di lakukan oleh menteri terhadap gubernur sebagai penanggungjawab penyelenggara pengelolaan usaha pertambangan di era otonomi daerah sesuai kewenangannya.

(b) Pengawasan yang dilakukan oleh pemerintah dan pemerintah daerah (menteri, gubernur) ditujukan terhadap pelaku usaha pertambangan.

3. Penerapan Hukum yang dapat dilakukan oleh pemerintah dalam mengatasi Aktifitas pertambangan emas yang tidak menjalankan kewajiban usaha pertambangan berdasarkan UndangUndang No. 4 Tahun 2009 Tentang Pertambangan Mineral dan Batubara adalah menjatuhkan sanksi berupa sanksi administratif dalam bentuk :

(a) Peringatan tertulis;

(b) Penghentian sementara sebagian atau seluruh kegiatan eksplorasi atau operasi produksi; dan/atau

(c) Pencabutan IUP.

Pejabat yang berhak menjatuhkan sanksi adalah pemerintah (menteri) dan pemerintah daerah provinsi.

Dan dalam hal pemerintah daerah tidak melaksanakan ketentuan sebagaimana yang dimaksud dalam pasal 151 dan hasil evaluasi yang dilakukan oleh menteri sebagaimana dimaksud dalam pasal 6 ayat (1) huruf j, Menteri dapat menghentikan sementara dan/atau mencabut IUP sesuai dengan ketentuan peraturan perundangundangan.

\section{B. Saran}

1. Pelanggaran-pelanggaran kegiatan Pertambangan terkait kewajiban IUP harus mendapat perhatian yang besar dari negara terlebih pembentuk undang- undang, dalam hal kepastian hukum pertambangan mineral dan batubara mengenai penyesuaian undang-undang no 4 tahun 2009 tentang mineral dan batubara dengan berlakunya undangundang no 23 tahun 2014 tentang pemerintahan daerah terkait kewenangan pengelolaan pelaksanaan pertambangan mineral dana batubara

2. Pemerintah pusat dan pemerintah daerah yang diberi kewenangan untuk mengawasi pertambangan mineral dan batubara harus lebih meningkatkan pengawasan terhadap pelaku usaha pertambangan agar perlindungan hukum antara pemerintah, pemegang IUP, dan masyarakat lokal dalam aktifitas Pertambangan semakin terlindungi dengan baik dan benar.

3. Keberadaan regulasi pada tindakan pelanggaran pelaksanaan usaha pertambangan terkait kewajiban IUP sangat di perlukan tatacara penerapan sanksi yang tegas dan lebih berat agar para pelaku pelanggaran tersebut mempunyai efek jerah.

\section{DAFTAR PUSTAKA}

Buku :

Hayati Tri, Era Baru Hukum Pertambangan Di Bawah Rezim UU No. 4 Tahun 2009, Cetakan 1, Yayasan Pustaka Obor Indonesia, Jakarta, 2015.

HS H. Salim., Hukum Pertambangan Di Indonesia, cetakanke-5, Rajawali Pers, Jakarta, 2010.

HS H. Salim., Hukum Pertambangan Mineral dan Batubara, Cet. 3, Sinar Grafika, Jakarta , 2014.

Manan Bagir, Menyongsong Fajar Otonomi daerah, Yogyakarta, Pusat Study

HAM (PSH), 2001

Gusnadi Kusnu, Harmonisasi Sistem Hukum Mewujudkan Tata Pemerintahan Yang Baik, Nasa Media, Malang, 2010.

\section{Peraturan Perundang-undangan}

Undang-Undang Dasar 1945

Kitab Undang-Undang Hukum Dagang (KUHD) 
Undang-undang No. 4 Tahun 2009 Tentang Pertambangan Mineral dan Batubara,

Undang-Undang No 23 Tahun 2014 Tentang Pemerintah Daerah.

Peraturan Menteri Energi dan Sumber Daya Mineral, Nomor 43 Tahun 2015 tentang Tata Cara Evaluasi Penerbitan Izin Usaha Pertambangan Mineral dan Batubara. Pasal 21 ayat 2.

Peraturan Pemerintah No 23 Tahun 2010 Tentang Pelaksanaan Kegiatan Usaha Pertambangan Mineral dan Batubara.

\section{Internet}

HSB Ali Marwan dan Evlyn Martha Julianthy, "Pelaksanaan kewenangan Atribusi Pemda Berdasarkan UU No 23 Tahun 2014 tentang Pemerintah Daerah", ejournal.peraturan.go.id.

http://media.neliti.com/media/publications/15 0756-ID-pengawasan-ataspenyelenggaraanpemerintah.pdf.

Murhani Suriansyah, Aspek Hukum Pengawasan Pemerintah Daerah, Laksbang Mediatama, Yogyakarta, 2008.

Panjuwa Govinda "Hak dan Kewajiban Pemegang Izin Usaha Pertambangan (IUP) dalam melaksanakan kegiatan usaha pertambangan", https://ejournal.unsrat.ac.id,.

Zaidah, "Izin Usaha Pertambangan setelah berlakunya Undang-Undang No 23 tahun 2014 Tentang Pemerintah daerah", https://fh.unram.ac.id.

adhayanto, oksep dan satyagraha, yudhanto adiputra, "dampak undang-undang no \ 23 tahun 2014 terhadap peraturan daerah di kabupaten bintan tahun 2015",https//media.neliti.com. diakses pada 6 desember 2019.

Member Of Astra, "Pengelolaan Hasil Tambang",
https//www.Agincourtresourc es.com 